\title{
PICTURA EXTERIOARĂ A BISERICILOR ORTODOXE, POARTĂ ŞI PURTĂTOARE A MESAJULUI SPIRITUAL
}

Mihaela Palade

\begin{abstract}
Vederea minunatelor biserici din Bucovina a trezit şi trezeşte, nu doar admiraţia şi chiar o stare de bucurie estetică cu conotaţii ekstatice, iar acesta nu doar în sufletul specialiştilor, ci şi al tuturor celor care se perindă prin preajma lor, într-un ritm mai mult sau mai puțin adecvat spațiului sacru respectiv. Câți însă din cei care întreprind acest pelerinaj exterior al bisericilor - destul de puține la număr, iar unele amplasate în locuri destul de retrase, în afara circuitelor turistice ${ }^{1}$ - ştiu ce se află cu adevărat în spatele faţadelor, de-a dreptul amețitoare prin informația lor cromatică? Iar dintre cei cărora li se explică ce anume teme sunt incluse în programul iconografic al bisericilor, câți sunt cei care reuşesc să le citească şi cu sufletul? Iar dintre aceştia, şi mai puțini sunt cei care încearcă să pătrundă şi în universul estetic, să le descifreze mecanismul secret de compunere a formelor picturale, majoritatea mulţuminduse cu bucuria amintirii celor văzute. Studiul de faţă îşi propune să descifreze, fie chiar şi parțial, un anume sens pe care îl are pictura exterioară.
\end{abstract}

Keywords: pictură, arhitectură, culoare, materialitate, fereastră, poartă.

\section{Pictura exterioară a bisericilor bucovinene}

Parcurgerea, fie ea superficială şi sumară, a unor biserici din nordul Moldovei oferă până şi celor necunoscători sau neavizați

\footnotetext{
${ }^{1}$ Dacă Voroneț - această „Sixtină a picturii moldave” cum a fost numită, din pricina Judecății de Apoi - se află, împreună cu Humor, Moldovița şi Sucevița, în calea turiştilor amatori de inedit, dacă municipiul Suceava găzduieşte două biserici impozante - Sfântul Gheorghe şi Sfântul Dumitru -, în schimb, Probota, Baia şi Arbore se află amplasate în zone mai puțin cunoscute şi mediatizate.
} 
surpriza unor imense edificii îmbrăcate integral în veşmântul pictural sau, altfel spus, complet „îmbăiate” într-un complicat şi fascinant complex de forme şi culori ce şi-au păstrat, în majoritatea lor, structura plastică originară, posibil a fi descifrată total sau măcar parțial.

Bisericile care şi-au păstrat încă podoaba picturală într-o formă care să permită descifrarea ei sunt: Probota (1530), Sfântul Gheorghe Suceava (1532-1534), Humor (1535), Moldovița (1537), Sfântul Dumitru Suceava (1535), Baia (1535-1538), Sfântul Ilie Suceava, Arbore (1541), Voroneț (1547), Râşca (1552), Sucevița (1595-1596). Cu privire la arhitectura bisericilor veacului al VI-lea nu au venit cu modificări notabile, ele repetând formula de la biserica Mănăstirii Neamț.

Noutatea majoră a apărut în plastica decorativă a fațadelor, acolo unde meşterii lui Petru Rareş au intervenit cu ideea remarcabilă de a înlocui decorul anterior, în care materialele aparente - piatră brută, cioplitură, cărămidă smălțuită şi divers colorată, ornamente de pământ ars smălțuit - erau puse în operă cu abilitate, cu zone etajate sau compoziții monumentale de picturi în frescă „,ce îmbracă pereții în întregime, de la soclu până la streaşină"2.

De la început se remarcă faptul că pictura exterioară îmbracă integral corpul bisericii, iar programul iconografic prezintă coerenţă şi consecvență astfel că, încă de la intrarea pe poarta mănăstirilor, ceea ce uimeşte la vederea acestor faţade integral pictate este „neprevăzutul, surpriza actului”" ${ }^{3}$ neobişnuita modalitate de a împodobi o fațadă de biserică. Zugravul moldovean a fost preocupat să acopere ,în întregime toate suprafețele cu pictură, indiferent de natura lor arhitectonică (fațade plane, abside sferice, firide, ocnițe, contraforturi etc)", elementelor arhitecturale, de forma, dimensiunile şi desfăşurarea lor în spațiu, ele devin, obligatoriu, suport pictural.

2 Grigore Ionescu, Arhitectura pe teritoriul României, Bucureşti, Edit. Academiei R. S. R., 1981, pp. 291-292.

${ }^{3}$ Anca Vasiliu, La traversé de l'image, p. 9.

${ }^{4}$ Irineu Crăciunaş, Bisericile cu pictură exterioară din Moldova (I), p. 418. 
Farmecul generat de ineditul modalității de împodobire a bisericilor, de frumusețea lor cromatică face ca părerea quasiunanimă să fie aceea de armonie universală, bisericile respective părând a fi quintesența frumuseții. Remarcile, de regulă reținute, ale obiectivelor tratate de istoria artei lor capătă tonuri exclamative în fața unor asemenea picturi: „Ce uimitoare îndrăzneală! Meşterii moldoveni zugrăveau pereții exteriori ai bisericilor fără să se teamă de faptul că culorile din natură ar putea să le facă să pălească. Figurile sunt adesea desenate pe un fond albastru viu după cum însăşi biserica se profilează pe azurul cerului. În nici o altă țară din Europa, nici măcar în patria clasică a picturii murale, în Italia, nu vom găsi ceva cât de cât asemănător cu aceste biserici ale căror culori armonioase scânteiază pe verdele poienilor, pe fondul tremurat al dealurilor din frumoasa Moldovă"s, acesta fiind şi motivul pentru care modalitatea de raportare a picturii la arhitectură şi reciproc poate avea varii interpretări.

\section{Specificitatea picturii în raport cu arhitectura}

Deşi diferite ca raportare volumetrică, ambele ramuri ale artei, atât arhitectura, cât şi pictura, operează cu forme, care se pot prezenta ca volume sau ca suprafețe, în ambele cazuri „,condiția lor spațială fiind definitorie. Distingem astfel formele bidimensionale şi formele tridimensionale. Când forma bidimensională ni se impune ca reprezentare a ceva perceptibil vizual ... ea se pretează înțelegerii noastre în calitate de imagine" ${ }^{\text {. }}$. Astfel, am putea spune că una se raportează la forme tridimensionale, alta la planeitatea bidimensională.

Prozaic, $D E X$-ul defineşte arhitectura ca fiind: „1) Ştiinţa şi arta de a proiecta şi construi clădiri. 2) Stilul, caracterul, planul unei (sau unor) clădiri. 3) Felul în care este construit sau alcătuit ceva".

\footnotetext{
${ }^{5}$ Mihail Alpatov, Istoria Artei, vol. I, traducere de Bruno Colbert şi Mihai Ibăţescu, Bucureşti, Edit. Meridiane, 1967, pp. 373-374.

${ }^{6}$ Gheorghe Achiței, Frumosul dincolo de artă, Bucureşti, Edit. Meridiane, 1988, p. 66.
} 
Iar în Dicționarul de neologisme, ea este „1. Ştiința şi arta de a proiecta şi de a construi clădiri potrivit anumitor proporţii şi reguli, determinate de caracterul şi de destinația construcțiilor. 2. Stilul, caracterul distinctiv al unei construcții sau al unei epoci. 3. (Fig.) Structură armonioasă (mai ales a unei opere literare). Alcătuire internă; construcție; constituție"7 . Aşadar, în mentalitatea curentă, arhitectura presupune întotdeauna o construcție bine alcătuită, organizată şi structurată logic.

Dicționarul de artă expediază termenul ,arhitectură” în câteva rânduri - ea fiind definită „arta de a construi după legi specifice, la început empiric descoperite, ulterior statuate de teoreticieni" ${ }^{\prime}$ - poate şi datorită statutului mai special, acela de a pendula între artă şi ştiinţă mai mult decât alte ramuri artistice. Definițiile poetice văd arhitectura ca fiind ,muzică împietrită" (F. W. J. Schelling) sau ,sculptură locuită" (Constantin Brâncuşi) sau ,arta de a compune o sculptură pentru un amplasament anumit şi de a o instala acolo, urmând principiile unei construcții alese"9.

Cât priveşte pictura, dicţionarele fără mari pretenții de subtilități estetice o prezintă ca fiind: „1. ramură a artelor plastice care interpretează realitatea în imagini vizuale, prin forme colorate, bidimensionale, desfăş̧urate pe o suprafață plană. 2. lucrare artistică executată de un pictor: tablou, pânză. Ansamblul creațiilor plastice care definesc personalitatea unui pictor. Ansamblul operelor, stilurilor şi procedeelor specifice pictorilor dintr-o țară, dintr-o epocă, dintr-o şcoală etc. 3. (fig.) descriere sugestivă (într-o operă beletristică) a fizicului şi a caracterului personajelor, a unor scene din viața reală şi din natură etc" 10 .

Dacă, după P. Michelis, arhitectura operează cu trei elemente de morfologie arhitecturală, masa, spațiul şi lumina ${ }^{11}$, dintre care

\footnotetext{
${ }^{7} \mathrm{http} / / /$ dexonline.ro/definitie/arhitectura, accesat 16 sept. 2011.

$8 * * *$, Dicționar de artă, vol. I, p. 37.

9 John Ruskin, Lectures on Architecture and Painting, în vol. „Arhitectura ca artă”, Bucureşti, Edit. Meridiane, 1987, p. 364.

${ }^{10} \mathrm{DEX}$, http://dexonline.ro/definitie/pictura, accesat 16 sept. 2011.

${ }^{11}$ Panayotis Michelis, Estetica arhitecturii, p. 231.
} 
primele două presupun tridimensionalul, a treia punându-le în valoare, pictura se raportează întotdeauna la bidimensional. Aceasta este şi particularitatea definirii picturii în planul estetic, ea fiind considerată o „modalitate de expresie prin mijloace comunicabile vizual, căreia, indiferent de genul ei (monumentală, de şevalet, ornamentală, de ilustrație) sau de tehnica şi de materia în care este efectuată (frescă, ulei, guaşă, pastel, etc), indiferent de suportul pe care este lucrată (zid, lemn, pânză, carton, hârtie, mătase, porțelan, ceramică) şi indiferent de viziunea şi concepția care se află la baza ei, îi sunt caracteristice prezentarea bidimensională (s.n.), pe o suprafață plată, a unor forme colorate" 12 .

Din acest punct de vedere, cu alte cuvinte dintr-unul „clasic”, faptul că ea poate decora şi volume reprezintă o excepție, căci prin însăşi structura şi modul de punere în operă, ea se desfăşoară pe suprafețe, fie ele plane sau curbe, de forme dintre cele mai diverse, generoase sau restrânse ca dimensiuni şi având proporții variabile. Odată ajunşi în acest punct, apare o nouă modalitate de vedere a bisericilor pictate, ca unele ce transformă arhitectura în pictură.

\section{O nouă materialitate - bisericile pictate}

Orice material nu valorează numai pentru calitățile sale de întrebuințare, ci şi pentru „calitățile sale propriu-zis sensibile care, întrucât se oferă percepției, pot conlucra la compunerea obiectului estetic. Din punct de vedere estetic, materialul nu se prezintă numai ca material - ceea ce este el pentru artist este tot aşa de bine şi pentru artizan -, ci şi ca suport al sensibilului; el este acolo pentru apariție, pentru a compune un obiect destinat contemplației şi nu utilizării” ${ }^{\prime 3}$.

Se ştie că materiile au un ,destin, sau dacă vreți, ele au o anumită, vocație formală. Ele au o consistență, o culoare, o granulație. Ele sunt formă, aşa cum spuneam, şi chiar prin aceasta, ele cheamă, limitează sau dezvoltă viața formelor artei. Ele sunt alese

\footnotetext{
$12 * * *$, Dicționar de estetică generală, p. 267.

${ }^{13}$ Mikel Dufrenne, Fenomenologia experienței estetice, p. 403.
} 
nu numai în funcție de uşurința cu care pot fi prelucrate, sau în măsura în care arta se pune în slujba vieții, de pertinența lor utilitară, dar şi pentru că ele favorizează o anumită tehnică şi produc anumite efecte. Astfel forma lor, în stare brută, suscită, sugerează, propagă alte forme, ca să reluăm o expresie aparent contradictorie" ${ }^{\text {"14 }}$. Odată ce sunt puse în operă, are loc un divorț între materiile artei şi materiile naturii, instituindu-se o nouă ordine, în sensul că „lemnul statuii nu mai este lemnul arborelui; marmura sculptată nu mai este cea din carieră ..." ${ }^{\prime 15}$ S-ar mai putea vorbi însă de aceeaşi materie atunci când ea migrează dintr-o formă într-alta?

În cazul bisericilor moldoveneşti, formele arhitecturale au rămas aceleaşi, cu mici excepții, ca aceea de la Voroneț (unde s-a renunțat la ferestrele vestice). În rest, aceeaşi masă construită a corpului bisericii şi a turlei, aceleaşi dimensiuni generatoare de suprafețe largi, aceleaşi punctări ale golurilor pe faţade. Dar aceste forme arhitecturale au devenit altceva, însă nu printr-o modificare structurală survenită asupra lor, ci prin simpla interventie picturală. A fost operată doar o schimbare a materiei. Forma oricărei opere de artă este, la urma urmei, o ,formă materială”, iar dacă arta conferă materiei prestigiu pentru a releva ceea ce vrea, ea nu o face ,prin materie, ci prin spiritul formei"16.

Iar specificul arhitecturii este că ea ,dobândeşte graţia şi unitatea formei atunci când exprimă victoria ideii asupra materiei pe care o spiritualizează. În acest caz, materia se eliberează de propriile sale poveri"17. Eliberarea de propriile poveri nu presupune însă aruncarea peste bord a ,poverii” esențiale. Înainte de a fi o artă a spațiului, arhitectura este una a volumelor, iar dacă spațiul îşi permite luxul de a pluti undeva, ,în aer", în sferele înalte ale cerului - motiv pentru care nu întâmplător este asociat cu aerul, opusul materialității -, volumetria este indicat să fie ,„cu picioarele pe pământ”.

\footnotetext{
${ }^{14}$ Henri Focillon, Viața formelor, pp. 68-69.

${ }^{15}$ Ibidem, p. 69.

${ }^{16}$ Panayotis Michelis, op. cit., p. 247.

${ }^{17}$ Ibidem, p. 247.
} 
Arhitectura presupune tocmai greutatea materiei, asociată cu stabilitatea, siguranța, echilibrul, nu întâmplător piatra este unul din materialele de construcție preferate, nu doar datorită durității, rezistenței la eroziune, cât mai ales din pricina mesajului mintal transmis. Ea este şi rămâne „tare ca piatra”, adică durabilă, sinonimă veşniciei.

În acelaşi timp însă, în paralel cu ispita solidităţii şi stabilității materiei, s-a dorit eliberarea de sub tutela ei apăsătoare, prea „materială”, opusă deci spiritualului. Cea mai supărătoare constrângere este simțită din interiorul spațiilor arhitecturale, acolo unde totul este îngrădit, delimitat de materialul turnat în formele proiectate în prealabil. Aşa că una din posibilităţile de anulare a materiei a constituit-o spargerea ei, anularea ei opacităţii ei fizice prin înlocuirea cu sticla - ceva transparent, care permitea vizibilitatea şi iluzia dematerializării.

Din acest motiv, putem spune că ispita dematerializării învelişului arhitectural este una veche, poate tot la fel de veche ca materialul însuşi. Odată cu necesitatea delimitării şi îngrădirii spațiului, din considerente practice absolut necesare, s-a născut şi dorința de a trece dincolo de această barieră, cea mai firească formulă fiind cea a vitrării suprafețelor.

Sfânta Sofia din Constantinopol constituie unul din modelele de biserică bizantină în care, datorită bandoului de ferestre aflat la baza cupolei masive, aceasta parcă pluteşte, realizându-se astfel o dematerializare a spațiului ce umple de încântare sufletele şi în prezent, aşa cum a făcut-o şi cu un mileniu şi jumătate în urmă. Per total însă, bisericile bizantine se remarcă prin semiobscuritatea care domneşte în interior, cu semnificații simbolice prea bine cunoscute.

De la catedralele gotice - despre care s-ar putea afirma că nu mai sunt constituite din piatră, ci din sticla vitraliilor - până la arhitectura din oțel şi sticlă, nu e decât un pas, deşi istoria a înregistrat ceva mai mult. În secolul trecut, discursul arhitectural al lui Frank Lloyd Wright a realizat trecerea de la masivitate la dematerializarea treptată prin încercarea de a depăşi spațiul capsulat al cutiei. Spargerea spațiului arhitectural a constituit o realizare a 
caselor proiectate de ele, îndeosebi cele din prerie, şi care s-au constituit ele în sine ca model arhitectural. Punctul maxim a fost atins în Waterfall House şi Robie House, caz în care spargerea cutiei se face la nivelul acoperişului prin bandoul de ferestre de sub acoperiş, făcându-l pe acesta ca să plutească.

Din moment ce s-a vehiculat ideea „morții artei” (ce-i drept, văzută de un filosof), firesc s-ar putea vorbi şi despre „,moartea arhitecturii” (tot dintr-un unghi filosofic). O formă ar fi „,moartea prin transparență", aspect semnalat destul de recent de Augustin Ioan: ,în vremea din urmă, asistăm la o altă dispariție a arhitecturii, de data aceasta datorită sticlei. Ne aflăm sub tirania văzului în ce priveşte experiența empirică a arhitecturii, în detrimentul tuturor celorlalte simțuri... Pe măsură ce văzul reprezenta tot mai mult modul privilegiat de investigare a arhitecturii, în chip paradoxal fațadele deveneau tot mai desubstanțiate" ${ }^{\prime 18}$. Iar a privi din exterior interiorul nu e totuna cu a privi exteriorul din interior, motiv pentru care problema transparenței totale ar putea fi mai mult decât o abolire a materialelor tradiționale.

La fel şi în contemplarea unei biserici, există însă două unghiuri de vedere, unul în care materia este privită din interior, altul din exterior, percepția nefiind sinonimă - nici măcar similară acelui joc de pozitiv-negativ şi viceversa. Privit din interior, o formă de anulare a materiei apare în bisericile în care fondul picturilor, indiferent de tematica lor, este, de regulă, auriu sau albastru. S-a vorbit îndelung despre dematerializarea bisericilor bizantine, datorată, în principal, picturii care străpunge practic masivitatea zidului. Fondul auriu sau albastru al frescelor - în ultima situație el fiind tratat adesea uniform, fără vibrări ale suprafeței picturale, uneori doar cu punctările imprimate de auriul stelelor - reprezintă o masă picturală neutră care nu atrage atenția asupra sa, ci lasă privirea să pătrundă dincolo, către nevăzutul pe care cele văzute izbutesc doar să-1 sugereze.

18 Augustin Ioan, Khora. Teme şi dificultăți ale relației dintre filozofie şi arhitectură, Bucureşti, Edit. Paideia, 1999, p. 23. 
A fost îndelung discutat efectul vizual cu totul spectaculos al mozaicurilor cu fond de aur, prezent atât la începutul Bizanțului, cât şi în ultimele lui zile, „trăgându-se poate prea pripit concluzia că intenția artiştilor bizantini era aceea de a dematerializa elementele constructive ale bisericilor, dizolvându-le în lumină" ${ }^{\prime 19}$. Iar unul dintre marii arhitecți ai secolului XX afirma faptul că ,prin acoperirea tuturor pereților $\mathrm{cu}$ mozaicuri, este negat orice contrapunct de greutate şi de sprijin, pereții lucioşi şi scânteietori devin un veşmânt de materie uşoară, moale şi subțire ..."20

În mai toate tratatele de teologia icoanei se subliniază faptul că fondul respectiv trimite dincolo de materia zidului care obturează lumina soarelui, dar nu către lumina fizică, ci către lumina necreată. În limbajul tehnic al iconarilor, „fondul însuşi al icoanei se numeşte «lumină»" 21 , lumina fiind energie divină, motiv pentru care putem spune că ea este esențială conținutului icoanei, „căci lumina stă la baza limbajului simbolic. Trebuie să precizăm: fondul icoanei simbolizează lumina, indiferent de culoarea lui, deşi reprezentarea cea mai adecvată este aurul, care este prin fire străin de culori şi nu se armonizează cu ele; dar folosirea culorilor de fond - ca «lumină» - nu contrazice sensul acesteia, deşi îi reduce puterea semnificativă" ${ }^{\prime 22}$. Trimiţând către lumină, fundalul auriu sau albastru al picturii bizantine ,îmblânzeşte” duritatea materiei, opacă „ca un zid" la încercările de înlăturare a îngrădirilor de orice fel.

Aceasta este şi rămâne valabil în interiorul bisericilor. Ce se întâmplă însă atunci când pictura, element decorativ cu multiple semnificații, definind de aproape un mileniu şi jumătate doar spațiul interior, ajunge acum să invadeze suprafaţa exterioară şi nu doar parțial, ci total? În plus, situația respectivă a apărut într-o conjunctură

\footnotetext{
19 Ana Elisabeta Botez, Materie şi semnificație în arhitectura bisericilor răsăritene, teza de doctorat, susținută la Universitatea de Arhitectură şi Urbanism „Ion Mincu” Bucureşti, Bucureşti, 2011, p. 112.

${ }^{20}$ Bruno Zevi, Cum să înțelegem arhitectura, Bucureşti, Edit. Tehnică, 1969, p. 102.

${ }^{21}$ Leonid Uspensky, Teologia icoanei, p. 130.

${ }^{22}$ Ibidem, p. 207.
} 
arhitecturală care îşi stabilise un anume limbaj decorativ, cu totul remarcabil prin coerența, armonia şi frumusețea sa.

Într-o biserică cu fragmente pictate, în firide şi ocnițe, din secolul al XV-lea, pictura este un ingredient benefic vizual, care se alătură celorlalte materiale ce constituie paramentul specific bisericilor lui Ştefan cel Mare. Alături de discurile ceramice pictate, alături de cărămizile smălțuite şi de celelalte materiale ceva mai şterse, pictura vine cu o textură nouă, şi mai ales o cromatică infinit mai variată, care a îmbogățit paleta coloristică a fațadelor. Dar ea nu s-a impus cu ostentație, ci a rămas undeva - la propriu şi la figurat în umbra nişelor din partea superioară a bisericilor.

Pe când în cazul celor din veacul următor, ,în loc însă ca aceste faţade să arate, ca în vremea lui Ştefan cel Mare, materialul din cari sunt construite şi să aibă o ornamentație de cărămidă aparentă, smălțuite sau nu, şi de discuri, aceste fațade sunt tencuite şi zugrăvite peste tot, de la profilul soclului până la straşină, şi de la învelitoare în sus, pe bazele turlei şi pe turla însăşi’" ${ }^{23}$, fapt care le transformă în altceva. Pictura a părăsit firidele şi ocnițele în care şezuse smerită până atunci, pentru a invada practic corpul arhitectural în totalitatea lui, într-un soi de acaparare care, dacă nu ar fi plăcută ochiului, ar părea de-a dreptul agresivă.

Din acest motiv, diferența dintre o biserică de la sfârşitul veacului XV şi una de la începutul celui următor nu este una de evoluţie temporală în planul aceloraşi idei, ci de o schimbare totală a principiilor estetice specifice rezolvării plastice a fațadelor. S-ar putea vorbi astfel de o nouă materialitate. În final, se pune totuşi întrebarea dacă nu ar fi mai potrivit termenul de transfigurare a materiei, în locul dematerializării atât de des uzitată. După cum remarca un arhitect contemporan, dacă arhitectura gotică tinde către

${ }^{23}$ Gheorghe Balş, Bisericile şi mănăstirile moldoveneşti din veacul al XVI-lea, p. 226. 
dematerializare $^{24}$, arhitectura bizantină este masa constructivă „, transfigurată de lumină ${ }^{, 25}$.

Privită din interior, într-adevăr o biserică de tradiție bizantină poate fi un Tabor arhitectural, în care lumina transfigurează spaţiul şi materia. Privită din exterior, o biserică pictată din Bucovina ar putea fi un Tabor pictural, în care materia arhitecturală a suferit o transfigurare cromatică sau, mai degrabă, o poartă prin care se poate pătrunde, încă din curtea mănăstirii, în spațiul cultic al bisericii.

\section{Pictura exterioară a bisericilor - poartă a spațiului cultic}

Odată intrați pe poarta mănăstirilor, fascinează podoaba exterioară a bisericilor, un similară celei pe care ne aşteptăm să o aflăm în interior. Aria sa de interpretare este una destul de largă, putându-se vorbi de ziduri care nu doar îmbracă un spaţiu, delimitându-1 structural, ci depăşesc statutul de înveliş material, cu lamentabile conotații practice. Ele anunță şi se pronunță cu privire la profilul utilitar al spațiului respectiv, asemenea unor imense „cărți de vizită". Astfel că, din punctul de vedere al dezvăluirii destinației edificiului arhitectural, pictura bisericilor moldoveneşti este cea care atenționează dintru început asupra sentimentului sacralităţii, imprimând şi trăirea adecvată.

De regulă, arhitectura este considerată a fi cea care creează „spații ce evocă sentimentul unei utilizări adecvate”, după cum se

${ }^{24}$ Andrew Gould, On Earth as it is in Heaven, Form and Meaningin Orthodox Architecture, p. 2, http://www.newworldbyzantine.com/articles/pdf/, accesat 11 august 2012.

25 „In unele biserici bizantine fereastra este din alabastru translucid sau marmură, astfel încât lumina pare să strălucească din zidul însuşi. Mozaicuri de aur sau fresce strălucitoare pun în joc lumina pe suprafețe multiple. Lămpi cizelate şi mobile incizate reflectă lumina din fiecare direcție. Naosurile adânci sau capele laterale în spatele arcadelor par umbre misterioase şi îndepărtate, ceea ce face ca biserica să pară, prin contrast, şi mai strălucitoare. Aceasta este masa transfigurată de lumină. E aceeaşi lumină ca şi aceea din icoane, sacră şi atotpătrunzătoare, lumina Necreată care vine de la dumnezeu către creația lui. Piatra şi ghipsul strălucesc dinăuntru". Andrew Gould, art. cit., pp. 2-3. 
exprima Louis Kahn, arhitect fireşte. Astfel, se recunoaşte „nevoia de a considera o clădire ca pe un simbol al activității adăpostite înăuntrul ei. Prin înfățişarea lor, o şcoală, o biserică, o clădire administrativă şi un sediu guvernamental trebuie să fie identificabile de către cei ce le utilizează ca şi de către cei ce trec pe lângă ele sau prin ele" 26 , destinația lor fiind citită nu doar în plăcuţa obligatorie de la intrare, ci în însăşi profilul lor stilistic.

Ceea ce se poate numi „funcția simbolică” a arhitecturii este dependentă de vocabularul formelor alese, astfel că o biserică de tradiție ortodoxă, indiferent de perioada edificării ei, păstrează o anume tipologie spaţială şi o anume volumetrie. Forma alungită, simbolism al corabiei, structura spaţială tripartită care se citeşte în exterior, prezența obligatorie a absidei altarului şi, dacă se poate, a absidelor laterale, turla care încununează triumfător corpul bisericii, crucea prezentă în părțile cele mai înalte ale volumetriei sunt doar câteva dintre elementele care definesc o biserică ortodoxă. În cazul bisericilor moldoveneşti mai apare un element, de data acesta de natură picturală, care se adaugă tipologiei specifice a formelor arhitecturale şi care, prin programul iconografic şi stilul specific, vine să întărească destinația sacră a edificiului eclesial, şi anume pictura care „,ia vederea”, acoperind zidul - şi la propriu, şi la figurat.

Zidul, prin definiție, datorită însăşi structurii şi destinației sale constructive, de element de rezistență, este impermeabil, de nestrăbătut şi de nestrămutat. Oricât de frumos ar fi realizat, oricât de interesant şi fascinant ar fi din punct de vedere estetic, el este perceput a fi un obstacol, o barieră aparent insurmontabilă, plinul fiind prin definiție perceput ca fiind opusul golului. Din acest motiv, imposibilitatea de depăşire a opacităţii constituie o provocare, incitând către găsirea unor modalităţi de anulare şi de străpungere a zidului.

Dacă pictura bizantină este o pictură care desființează greutatea materială a zidului, masa sa constructivă, pentru a oferi o vedere a acelei transparențe a materialității, poartă către

${ }^{26}$ Nathan Knobler, Dialogul vizual, p. 96. 
transcendent, dacă în cadrul arhitecturii religioase şi civile se recurge la dematerializare prin vitrare, arhitectura moldovenească nu a recurs la îndepărtarea materiei, ci, prin acoperirea cu o haină picturală, a dematerializat-o prin transfigurare. Astfel că, din punctul de vedere al materialității, pictura exterioară reprezintă tocmai o ,spargere” a învelişului exterior şi o pătrundere în forma decorativă a spatiului interior, chiar dacă aceasta nu constituie un scop în sine.

Pe lângă atributul său estetic de necontestat, pictura exterioară mai are unul, acela de a fi poartă către imensa bogăţie de semnificații a spațiului interior, îndeosebi cea cultică. Lucrarea de faţă nu vizează prezentarea atributelor şi a menirii icoanei şi a picturii în lumea ortodoxă, în acest sens existând o bogată şi avizată literatură de specialitate $^{27}$. În vederea citirii cât de cât complete a semnificațiilor picturii bizantine, este însă un aspect asupra căruia este necesar să mă opresc. S-a spus despre icoană că este o ,fereastră spre absolut". Expresiei respective i-a fost închinată o carte ${ }^{28}$ şi a intrat în uzul curent al vocabularului iconic.

Numai că fereastra constituie, paradoxal, un obstacol în faţa căruia trupul se opreşte pentru a permite doar privirii să treacă, motiv pentru care ea a constituit o temă predilectă a pictorilor interesați în a reda melancolia şi visarea la care predispune imposibilitatea transcenderii dincolo de spaţiul închis al camerei obturate de ziduri ${ }^{29}$. De altfel, fereastra este un gol practicat în zid cu scopul de a lumina un spațiu zidit, de a oferi posibilitatea admirării exteriorului (sau, în sens invers, a interiorului) şi nu de a permite accesul.

Spre deosebire de fereastră, poarta reprezintă un gol în zid prin care se poate pătrunde, nu doar imaginar şi vizual, ci şi real, dincolo de zid. Din acest motiv icoana poate fi mai mult decât o

${ }^{27}$ Din păcate, uneori prea debordantă în interpretări care se pierd într-un subiectivism îndoielnic.

${ }^{28}$ Michel Quenot, Icoana, fereastră spre absolut, traducere, prefaţă şi note de Pr. Dr. Vasile Răducă, Bucureşti, Edit. Enciclopedică, 1993.

${ }^{29}$ De pildă, „Waiting by the Window” de Carl Holsoe (1863-1935) sau variantele „Figure at a Window” de Salvator Dali, 1925, Museo Nacional Centro de Arte Reina Sofia, Madrid, Spain. 
fereastră în dreptul căreia te opreşti, ea este o poartă prin care se pătrunde în împărăția cerurilor, este adevărat, nu în chip real, ci potențial, întrucât în această lume nu putem avea parte decât de o pregustare a celor viitoare. Poarta simbolizează „locul de trecere dintre două stări, dintre două lumi, dintre cunoscut şi necunoscut, dintre lumină şi întuneric, dintre bogăţie şi sărăcie. Poarta se deschide spre mister. Dar ea are şi o valoare dinamică, psihologică; căci ea nu marchează doar un prag, ci îl şi invită pe om să îl treacă. Poarta este o invitație spre un alt tărâm. Trecerea prin poartă este, cel mai adesea în sens simbolic, o trecere de la profan la sacru"30, astfel că, în cazul bisericilor pictate în exterior, trecerea de la profanul spațiului exterior la sacrul celui interior are loc nu doar prin tradiționalul şi monumentalul portal, ci şi prin această formulă inedită a picturii. Icoana este o poartă prin care se trece în lumea rugăciunii, nu prin mijloacele obişnuite într-o astfel de situație, cele ale cuvântului, ci prin cele ce aparțin domeniului plastic, nişte forme de exprimare cu caracter propriu, ce se adaugă rugăciunii rostite.

Mai mult, în toate imnele bisericeşti, adevărate compendii de teologie cântată, nu apare termenul de „fereastră”, ci cel de „poartă”, adică elementul arhitectural prin care se intră, se pătrunde într-o altă lume, nu cel prin care ea este doar contemplată şi admirată. Crucea ne-a izbăvit de ,porțile morții”, iar la Pogorârea la iad a Mântuitorului se cântă: „înfricoşatu-s-au de Acesta mai-marii iadului, şi s-au ridicat porţile cele de durere; că a intrat Împăratul slavei, Hristos, zicând celor din legături: Ieşiţi! Şi celor din întuneric: Descoperiţi-vă!" ${ }^{11}$ Hristos este uşa care duce la Tatăl - „Nimeni nu vine la Tatăl decât prin Mine” (Ioan 14,6) -, iar nu fereastra.

Semnificativ pentru prezența firească a Maicii Domnului în pictura exterioară este faptul că atributul de „uşă” sau de „poartă” este transferat şi asupra ei. Cum se spune în cântările cultului

30 Jean Chevalier şi Alain Gheerbrant, Dicționar de simboluri, vol. III, Bucureşti, Edit. Artemis, 1995, p. 113.

${ }^{31}$ Stihiră la Doamne strigat-am..., glasul al patrulea, în Octoih Mare, care cuprinde cântările Învierii pentru toate zilele săptămânii pe cele opt glasuri bisericeşti, Bucureşti, Edit. IBMBOR, 2003, p. 345. 
ortodox, ,plinitu-s-au proorocirile cele pentru tine, Fecioară curată, că unul din prooroci te-a numit pe tine uşă la Eden, care dă spre Răsărit, prin care nimeni n-a trecut, decât numai Făcătorul tău şi a toată lumea”32. În rugăciuni se spune „Uşa milostivirii deschide-o nouă Născătoare de Dumnezeu...” sau „Ridicați, căpetenii, porțile voastre şi vă ridicați porţile cele veşnice şi va intra Împăratul slavei. Cine este acesta Împăratul slavei? Domnul puterilor, Acesta este Împăratul slavei" (Psalmi 23, 9-10).

În cazul bisericilor moldoveneşti, interesant este faptul că, exceptând motivele decorative, absolut fireşti şi necesare, întreaga pictură exterioară este o imensă icoană, chiar şi anumitele prezenţe profane fiind sacralizate printr-o participare adecvată. Tehnica frescei, tematica iconografică, stilul pictural, scara picturii, toate trimit către cea interioară, astfel că, odată intrați în curtea mănăstirii, perceperea, fie ea numai parțială, a picturii exterioare poartă fără echivoc către destinația cultică a edificiului pe care îl îmbracă.

\section{Bucură-te, uşa Domnului...}

Biserica ortodoxă, ca locaş de cult, este icoana Maicii Domnului, Fecioara fiind văzută, la rându-i, ca o biseric $a^{33}$, dar şi ca uşă/poartă prin care se pătrunde în Împărătia cerurilor: „Biserică şi uşă, cămară şi scaun al Împăratului eşti, Fecioară...”34 sau „Bucurăte, uşa Domnului cea neumblată. Bucură-te, zidul şi acoperământul celor ce aleargă la tine"35. În fața unei volumetrii covârşitor convexă, aşa cum este cea a bisericilor ortodoxe, aşadar în fața unei suprafețe care, prin însăşi forma ei, este tocmai opusul receptacolului, a chemării, pictura exterioară este cea care suplineşte această aparentă

\footnotetext{
${ }^{32}$ Stihiră la Înviere, glasul al patrulea, în Octoih, p. 344.

33 „Chivot ceresc te cunoaştem pe tine, Preacurată, care ai purtat nu tablele Legii cele scrise de Dumnezeu, ci pe Dătătorul Legii şi Ziditorul cerului şi al pământului.”, stihiră la Înviere, glasul al treilea, în Octoih, pp. 176-177.

${ }^{34}$ Stihoavnă la vecernie, glasul al cincilea, în Octoih, p. 346.

${ }^{35}$ Troparul, Octoih, p. 347.
} 
respingere formală, invitând la pătrunderea în spațiul cultic, icoană a împărăției.

Astfel că, în cazul bisericilor moldoveneşti, ceea ce este prin definiție bidimensional, pictura, se metamorfozează într-o imaginară structură arhitecturală, poarta, spațiu de chemare, de trecere către alt spaţiu, fără a recurge la mult-uzitatul trompe l'oeil specific barocului. Odată intrați pe poarta (arhitecturală) a incintei monahale, ne întâmpină, în toată solemnitatea şi monumentalitatea ei, fresca exterioară, altă poartă (picturală) care ne invită, ne cheamă, ne sileşte $^{36}$ să pătrundem (imaginar) în spaţiul eclesial înainte chiar de a trece (fizic) dincolo de ancadramentul gotic de la intrarea în biserică.

\section{Bibliografie}

1. $* * *$, Dicționar de artă, vol. I.

2. ***, Dicționar de estetică generală.

3. ***, Octoih Mare, care cuprinde cântările Invierii pentru toate zilele săptămânii pe cele opt glasuri bisericeşti, Bucureşti, Edit. IBMBOR, 2003.

4. Achiței, Gheorghe, Frumosul dincolo de artă, Bucureşti, Edit. Meridiane, 1988.

5. Alpatov, Mihail, Istoria Artei, vol. I, traducere de Bruno Colbert şi Mihai Ibățescu, Bucureşti, Edit. Meridiane, 1967.

6. Balş, Gheorghe, Bisericile şi mănăstirile moldoveneşti din veacul al XVI-lea.

7. Botez, Ana Elisabeta, Materie şi semnificație în arhitectura bisericilor răsăritene, teza de doctorat, susținută la Universitatea de Arhitectură şi Urbanism „Ion Mincu” Bucureşti, Bucureşti, 2011.

8. Chevalier, Jean şi Gheerbrant, Alain, Dicționar de simboluri, vol. III, Bucureşti, Edit. Artemis, 1995.

9. Crăciunaş, Irineu, Bisericile cu pictură exterioară din Moldova (I).

10. Dufrenne, Mikel, Fenomenologia experienței estetice.

${ }^{36}$ În parabola nunții fiului de împărat, atunci când au fost chemați la ospăț cei de pe drumuri, s-a spus ,sileşte-i să intre”(Luca 14, 23). 
11. Focillon, Henri, Viața formelor.

12. Gould, Andrew, On Earth as it is in Heaven, Form and Meaningin Orthodox Architecture, p. 2, http://www.newworldbyzantine.com/articles/pdf/, accesat 11 august 2012.

13. http://dexonline.ro/definitie/arhitectura, accesat 16 sept. 2011.

14. http://dexonline.ro/definitie/pictura, accesat 16 sept. 2011.

15. Ioan, Augustin, Khora. Teme şi dificultăți ale relației dintre filozofie şi arhitectură, Bucureşti, Edit. Paideia, 1999.

16. Ionescu, Grigore, Arhitectura pe teritoriul României, Bucureşti, Edit. Academiei R. S. R., 1981.

17. Knobler, Nathan, Dialogul vizual.

18. Michelis, Panayotis, Estetica arhitecturii.

19. Quenot, Michel, Icoana, fereastră spre absolut, traducere, prefaţă şi note de Pr. Dr. Vasile Răducă, Bucureşti, Edit. Enciclopedică, 1993.

20. Ruskin, John, Lectures on Architecture and Painting, în vol. „Arhitectura ca artă”, Bucureşti, Edit. Meridiane, 1987, p. 364.

21. Uspensky, Leonid, Teologia icoanei.

22. Vasiliu, Anca, La traversé de l'image.

23. Zevi, Bruno, Cum să ințelegem arhitectura, Bucureşti, Edit. Tehnică, 1969. 